\title{
Działalność Stowarzyszenia Grona Nauczycielskiego Uniwersytetu Stefana Batorego w Wilnie (1923-1939). Zarys problemu
}

\section{Activities of the Teaching Staff Association of the Stefan Batory University in Vilnius (1923-1939): An Outline of the Problem}

\begin{abstract}
ABSTRAKT
Podstawowym zamysłem autorki jest nakreślenie krótkiej historii powstania, struktury i celów działania oraz sposobów ich realizacji przez członków Stowarzyszenia Grona Nauczycielskiego Uniwersytetu Stefana Batorego w Wilnie (USB). Ważnq intencja artykułu jest także ukazanie źródeł do dziejów tego Stowarzyszenia, które moga być wykorzystane do dalszych badań. Stowarzyszenie to działało w latach 1923-1939 i skupiało nauczycieli akademickich Uniwersytetu Wileńskiego. Jego głównym celem było wspieranie rozwoju nauki w ogólności, a przede wszystkim pomoc w przygotowaniu nowej, dobrze wykształconej kadry nie tylko dla szkół wyższych, ale i innych ważnych instytucji w odrodzonym państwie polskim. Nie mniej ważnym celem w programie działania tego Stowarzyszenia była integracja środowiska uniwersyteckiego wokół ważnych zagadnień i spraw naukowych, a także bytowych nauczycieli akademickich
\end{abstract}

SLOWA KLUCZOWE Stowarzyszenie Grona Nauczycielskiego USB, Uniwersytet Stefana Batorego w Wilnie, cel i program Stowarzyszenia, członkowie Stowarzyszenia

\section{KEYWORDS}

USB Teaching Staff Association, Stefan Batory University in Vilnius, purpose and program of the Association, members of the Association

SPI Vol. 23, 2020/2

ISSN 2450-5358 e-ISSN 2450-5366 DOI: 10.12775/SPI.2020.2.003

Nadestano: 27.05.2020 Zaakceptowano: 29.06.2020 Artykuły i rozprawy 
oraz ich rodzin. Członkami Stowarzyszenia byli nauczyciele akademiccy wszystkich wydziałów Uniwersytetu Stefana Batorego. Informacje prezentowane w niniejszym szkicu sq wynikiem analizy przede wszystkim materiałów archiwalnych znajdujących się w spuściźnie jednego z członków Stowarzyszenia, mianowicie Tadeusza Czeżowskiego, który, przybywszy z Wilna do Torunia, był jednym z twórców uniwersytetu w Toruniu. Materiały te znajduja się w Archiwum Uniwersytetu Mikołaja Kopernika.

\section{ABSTRACT}

The author's basic intention is to sketch the short history of the foundation, its structure, and the goals of its activities, as well as the ways they are implemented by members of the Teaching Staff Association of Stefan Batory University in Vilnius. Another important intention of the article is to show the sources for the history of this Association, which can be used for further research. This Association was active in the period 1923-1939; it gathered academic teachers from Vilnius University. Its main goal was to support the development of science in general, and above all to help in the preparation of new, well-educated members of the staff not only for universities, but also for the other important institutions in the reborn Polish state. A no less important goal in the Association's activities was to integrate the university environment around important scientific issues, as well as to care about the living conditions of the students and their families. The members of the Association were academic teachers of all faculties of Stefan Batory University. The information presented in this outline is the result of an analysis primarily of archival materials found in the papers and memoirs of one of the members of the Association, Tadeusz Czeżowski, who at the time of his arrival in Torun from Vilnius was one of the founders of the University of Torun. These materials are available in the Archives of the Nicolaus Copernicus University.

\section{Uwagi wstępne}

W 2019 roku minęła 100. rocznica wskrzeszenia Uniwersytetu Wileńskiego, który był kontynuacją zamkniętej w 1832 roku uczelni (Gawrońska-Garstka 2016; Piechnik, Puchowski 1996; Opacki 1998; Wrzosek 1929). Od pierwszych lat wskrzeszonego Uniwersytetu Stefana Batorego (dalej w skrócie: USB) kształtowano jego strukturę, jeśli chodzi o wydziały. Warto przypomnieć, że 
w strukturze uniwersytetu funkcjonowało sześć wydziałów. Były to wydziały: Humanistyczny, Teologiczny, Prawa i Nauk Społecznych, Matematyczno-Przyrodniczy, Lekarski i Sztuk Pięknych. Z okazji setnej rocznicy powołania na nowo do życia tej uczelni warto przypomnieć niektóre fakty z dziejów tej instytucji naukowej tak ważnej dla nauki i kultury polskiej. Przesłanką do tego jest nie tylko jubileusz, ale godny przypomnienia fakt, że wielu nauczycieli akademickich z Uniwersytetu Stefana Batorego po II wojnie światowej tworzyło polskie uniwersytety lub zasilało kadry naukowe już istniejących uczelni ${ }^{1}$. Taką uczelnią, która ma „korzenie wileńskie”, jest Uniwersytet Mikołaja Kopernika w Toruniu, dlatego ten szkic poświęcam pamięci zasłużonych dla powstania Uczelni Toruńskiej nauczycieli akademickich przybyłych z Wilna do Torunia. Artykuł powstał na marginesie przygotowań książki pt. Pedagogika na Uniwersytecie Stefana Batorego (Szulakiewicz 2019). Główną intencją artykułu jest przedstawienie ogólnego zarysu celu powstania i kierunków działalności jednego ze stowarzyszeń, którego członkami byli nauczyciele akademiccy USB ${ }^{2}$. Nadmienię, że początki działalności Stowarzyszenia przypadają na pierwsze lata wskrzeszonego USB (Opacki 1998). Nie mniej ważnym celem niniejszego tekstu jest ukazanie źródeł, które pozostały po działalności tego Stowarzyszenia i mogą stanowić materiał do dalszych badań. Artykuł jest oparty na spuściźnie Tadeusza Czeżowskiego, znajdującej się w Archiwum Uniwersytetu Mikołaja Kopernika (A UMK, sygn. 309/80/II, j. 2043). Spuścizna dotycząca Stowarzyszenia Grona Nauczycielskiego (dalej w skrócie: SGN lub Stowarzyszenie) obejmuje 23 jednostki zawierające materiały z lat 1922-1939, dotyczące historii tej organizacji. Dla wyjaśnienia należy już na samym początku powiedzieć, że Tadeusz Czeżowski był skarbnikiem Stowarzyszenia. W spuściźnie znajdują się protokoły z posiedzeń, protokoły zjazdów Stałych Delegacji, statuty z lat 1923-1936, deklaracje członkostwa, listy członków i niezwykle skrupulatnie prowadzone księgi rachunkowe oraz dokumenty rozporządzeń prawnych dotyczących stowarzyszeń. Jednak nie sposób mówić o nauczycielach akademickich USB działających

1 Jeśli chodzi o liczbę przybyłych z Wilna do Torunia osób w ogóle, nie tylko nauczycieli akademickich, zob. Krasnodębski (2019).

$2 \mathrm{Na}$ USB funkcjonowało wiele stowarzyszeń naukowych, zob. Rocznik Uniwersytetu Stefana Batorego w Wilnie 1938-1939 (s. 174). 
w tym Stowarzyszeniu bez odniesień do literatury pamiętnikarskiej, zwłaszcza egodokumentów tych autorów, którzy byli niezwykle aktywnymi członkami Stowarzyszenia lub jako studenci obserwowali działalność w nim swoich mistrzów. Dla przykładu wśród autorów dokumentujących życie środowiska akademickiego USB należy wymienić Tadeusza Czeżowskiego, Konrada Górskiego, Ludwika Kolankowskiego, Wincentego Lutosławskiego, ks. Waleriana Meysztowicza, Ferdynanda Ruszczyca, Irenę Sławińską, Stanisława Stommę, Władysława Tatarkiewicza, Czesława Zgorzelskiego, ks. Bronisława Żongołlowicza ${ }^{3} \mathrm{i}$ innych.

\section{Powstanie, struktura i członkowie Stowarzyszenia}

W kształtującej swoją strukturę uczelni, poza jednostkami naukowo-dydaktycznymi, powstawało niemal od pierwszego roku wiele studenckich kół naukowych, stowarzyszeń naukowych, ideowo-wychowawczych, regionalnych, kulturalno-towarzyskich i sportowych ${ }^{4}$. Wśród kół naukowych w Roczniku Uniwersytetu Stefana Batorego w Wilnie 1938-1939 wymieniono aż 23 koła. Były to m.in. takie koła jak: Koło Polonistów, Koło Historyków, Koło Filologiczne, Koło Filozoficzne, Koło Teologów, Koło Archeologiczne, Koło Przyrodników, Koło Chemików, Koło Medyków i in. ${ }^{5}$. Kuratorami tych studenckich kół naukowych byli profesorowie, reprezentanci dyscyplin.

Jednym $\mathrm{z}$ ważnych stowarzyszeń skupiających pracowników wszystkich wydziałów, a nie studentów, było Stowarzyszenie Grona Nauczycielskiego USB. Działalność omawianego Stowarzyszenia przypada na okres międzywojenny, a dokładniej na lata 1923-19396. Warto dodać,że tego typu zrzeszenia funkcjonowaływ innych miastach uniwersyteckich takich jak: Warszawa, Kraków, Lwów. Z zachowanych w spuściźnie dokumentów wynika, że pierwsze działania mające na celu powołanie do życia Stowarzyszenie Grona Nauczycielskiego

3 Wykaz prac tych autorów podano w Bibliografii niniejszego artykułu.

4 Historię kół naukowych studenckich, których członkami byli przedstawiciele dyscyplin naukowych, opisał Stanisław Pigoń, zob. Pigoń (1929).

5 Rocznik Uniwersytetu Stefana Batorego w Wilnie 1938-1939 (s. 174).

$6 \quad \mathrm{Na}$ niektórych znajdujących się $\mathrm{w}$ dokumentacji pismach widnieje nazwa Zrzeszenie Profesorów i Docentów Uniwersytetu w Wilnie. 
w Wilnie rozpoczęto w 1922 roku (A UMK, sygn. 309/80/ II, j. 23). Od tego roku czyniono starania, aby takie zrzeszenie powstało, o czym świadczą pisma do władz polskich w sprawie zezwolenia na założenie Stowarzyszenia oraz pisma do władz uczelni w sprawie jego statutu i sposobu organizacji (A UMK, sygn. 309/80/II, j. 25). Biuro Stowarzyszenia mieściło się w gmachu głównym uniwersytetu. Założycielami stowarzyszenia byli ks. Bronisław Żongołłowicz, współorganizator wskrzeszonego USB, pierwszy dziekan Wydziału Teologicznego USB, wiceminister w Ministerstwie Wyznań Religijnych i Oświecenia Publicznego (1930-1936), współtwórca i urzędnik odpowiedzialny za wdrożenie ustawy o szkołach akademickich z 15 marca $1933^{7}$. Wśród założycieli byli także: dr Kazimierz Sławiński prof. USB (chemik, dziekan Wydziału Matematyczno-Przyrodniczego USB), dr Franciszek Bossowski prof. USB (prawnik, specjalista prawa rzymskiego i cywilnego, dziekan Wydziału Prawa i Nauk Społecznych), prof. Teofil Gryglewicz (bakteriolog) i Władysław Dziewulski (dyrektor obserwatorium astronomicznego w Wilnie, po wojnie profesor Uniwersytetu Mikołaja Kopernika w Toruniu).

Organami Stowarzyszenia były: Zarząd, Walne Zgromadzenie Członków i Komisja Rewizyjna (A UMK, sygn. 309/80/II, j. 23). Zarząd składał się pięciu członków wybieranych przez Walne Zgromadzenie z grona członków zwyczajnych. Dużą rolę w sprawnym funkcjonowaniu Stowarzyszenia pełniła Komisja Rewizyjna składająca z trzech członków, która znakomicie kontrolowała sprawy finansowe, darów, datków, subwencji, a jej skład był wybierany jedynie na jeden rok (A UMK, sygn. 309/80/ II, j. 28). Ze źródeł wynika, że Walne Zgromadzenie (A UMK, sygn. 309/80/II, j. 27) zwoływano corocznie w miesiącu marcu, ale można było zwołać nadzwyczajne posiedzenie na wniosek 1/10 członków, przy czym wniosek taki musiał być poparty podaniem powodów, albo też zwoływano je na wniosek Komisji Rewizyjnej.

Dla potrzeb doraźnych spraw powoływano specjalne komisje. Przykładowo w 1935 roku powołano komisję w celu ustalenia regulaminu Stypendium im. J. Piłsudskiego. W skład tej komisji weszli: ks. Ignacy Świrski (teolog), prof. Franciszek Bosswoski (prawnik),

Dla przypomnienia warto nadmienić, że w wyniku tej ustawy doszło do likwidacji katedry Stanisława Kota i Ludwika Jaxy-Bykowskiego. 
Iwo Jaworski (prawnik), Kazimierz Sławiński (chemik), Bogumił Jasinowski (historyk filozofii), Stanisław Hiller (histolog i embriolog), Jan Prüfer (entomolog), Ludomir Śledziński (malarz, rzeźbiarz).

Obowiązkiem przedstawicieli Stowarzyszenia było uczestniczenie w Zjazdach Delegatów (A UMK, sygn. 309/80/II, j. 42), chodzi o delegatów poszczególnych kól, których posiedzenia odbywały się w różnych miastach, m.in.: Krakowie, Warszawie, Poznaniu, Wilnie. Były to - jak określano w dokumentach - posiedzenia zjazdów stałych delegacji, a w ich pracy dużą rolę odgrywała delegacja wileńska przedstawiająca ważne dla funkcjonowania organizacji postulaty czy kierunki działania. Znaczenie udziału wileńskich przedstawicieli nie może dziwić, bowiem zazwyczaj w delegacji wileńskiej reprezentantami byli Tadeusz Czeżowski i Bogumił Jasinowski.

\section{Członkowie Stowarzyszenia}

Zgodnie ze statutem Stowarzyszenia członkowie dzielili się na:

- zwyczajnych (byli nimi profesorowie, zastępcy profesorów oraz docenci USB),

- nadzwyczajnych (mogli być nimi osoby, które sprawowały funkcje nauczycielskie i zawodowe),

- honorowych, których mianowało Walne Zgromadzenie.

W Statucie określone zostały zasady przyjmowania członków w poczet Stowarzyszenia (A UMK, sygn. 309/80/II, j. 23). Zarząd mógł odmówić przyjęcia danej osoby w poczet członków bez podania przyczyny. Wówczas kandydat mógł się odwołać do Walnego Zgromadzenia i w tej sytuacji odbywało się głosowanie tajne nad przyjęciem danego kandydata, które raczej przesądzało o jego przyjęciu. Kandydat zostawał przyjęty do grona wówczas, gdy opowiedziało się za przyjęciem co najmniej 2/3 obecnych. Członkowie zobowiązani byli wpłacać corocznie składki. Składki ustalono w następujących kwotach: 10 zł wpisowe jednorazowo i 5 zł składki miesięcznej. Składki te zasilały majątek Stowarzyszenia, oprócz nich na majątek składały się subwencje państwowe, dary i zapisy osób prywatnych.

Głosowanie na Walnym Zgromadzeniu odbywało się tajnie, jeśli postulat taki zgłosiło 10 członków. Wybory natomiast zawsze były tajne. W przypadku równej liczby głosów daną sprawę rozstrzygał 
przewodniczący, z czego wynika, że przewodniczący posiadał duże uprawnienia w tym zakresie.

Analizując listy członków Stowarzyszenia Grona Nauczycielskiego w poszczególnych latach, można zauważyć, że liczyło ono około 100 osób (A UMK, sygn. 309/80/II, j. 24). Przykładowo, według list liczba członków z lat 1933-1938 wynosiła od 87 do 104 członków w roku 1935, czyli w dwunastym roku jego funkcjonowania. $Z$ kolei w roku 1936 zarejestrowano 94 osoby wpłacające składki, w roku 1937 nieco mniej, bo 87 osób. Jeśli chodzi o liczbę członków Stowarzyszenia, interesujące mogą być informacje o ich przynależności do poszczególnych wydziałów uczelni:

- Wydział Matematyczno-Przyrodniczy: 26 członków,

- Wydział Lekarski: 22 członków,

- Wydział Humanistyczny: 21 członków ${ }^{8}$,

- Wydział Sztuk Pięknych: 5 członków,

- Wydział Teologiczny: 6 członków ${ }^{9}$

- Wydział Prawa i Nauk Społecznych: 11 członków ${ }^{10}$.

$\mathrm{Na}$ podstawie tych danych nie można jednak wyjaśnić w prosty sposób struktury osobowej ani tworzyć wizerunku Stowarzyszenia, bowiem liczba członków reprezentujących dany wydział była uzależniona od liczby zatrudnionych w nim nauczycieli akademickich. Niewątpliwie cieszyć może to, że w działalność Stowarzyszenia zaangażowana była duża liczba nauczycieli $\mathrm{z}$ trzech wydziałów: Matematyczno-Przyrodniczego, Humanistycznego i Lekarskiego. We władzach Stowarzyszenia dominowali profesorowie z Wydziału Humanistycznego.

8 Na liście reprezentującej Wydział Humanistyczny byli m.in.: Ludwik Chmaj, Tadeusz Czeżowski (skarbnik), Bogumił Jasinowski (sekretarz) i Jan Oko.

9 Wydział Teologiczny reprezentowali m.in.: ks. Czesław Falkowski, ks. Walerian Meysztowicz.

10 Liczba wszystkich członków Stowarzyszenia Grona Nauczycielskiego w Wilnie w porównaniu do liczby członków z innych uniwersytetów była stosunkowo znacząca, gdyż np. w Poznaniu było tylko 70 członków takiej organizacji. 


\section{Cele Stowarzyszenia i ich realizacja}

Zgodnie ze statutem, celem Stowarzyszenia było:

- popieranie interesów nauki, czyli podejmowanie inicjatyw służących rozwojowi nauki, w tym inicjatyw wydawniczych oraz służących instytucjonalizacji i popularyzacji nauki,

- opieka nad kandydatami na pracowników katedr uniwersyteckich,

- troska o zapewnienie profesorom, docentom i innym osobom sprawującym funkcje naukowe lub nauczycielskie odpowiedniego dla ich zawodu prestiżu w społeczeństwie, ochrona ich materialnych interesów i zbliżenie koleżeńskie,

- wzajemna pomoc materialna i wsparcie moralne,

- opieka nad wdowami i sierotami po zmarłych profesorach i docentach oraz po urzędnikach $\mathrm{z}$ wyższym wykształceniem.

$\mathrm{Na}$ podstawie analizy źródeł można stwierdzić w jaki sposób realizowane były tak zarysowane cele Stowarzyszenia i poprzez jakie formy organizacyjne to się dokonywało. Najogólniej rzecz ujmując, można owe formy organizacyjne przedstawić następująco:

- propagowanie celów stowarzyszenia w prasie,

- udział w zjazdach delegatów wszystkich stowarzyszeń w Polsce,

- przedstawianie potrzeb zrzeszenia i jej członków,

- zbieranie funduszy na cele zgodne ze statutem,

- wydawanie organu Stowarzyszenia,

- organizowanie kooperatyw ${ }^{11}$ spożywczych i kas wzajemnej pomocy,

- organizowanie kooperatyw wydawniczych (A UMK, sygn. 309/80/II, j. 23).

Realizację celów Stowarzyszenia na forum ogólnopolskim można odtworzyć na podstawie sprawozdań delegacji stałych reprezentowanych przez to Stowarzyszenie, działających w poszczególnych miastach akademickich. Natomiast w Wilnie, jak wynika ze sprawozdań, realizowano głównie cele, które można określić jako zadania regionalne. Jednak członkowie Stowarzyszenia podejmowali również sprawy ogólnopolskie. Przykładowo, wileńskie Stowarzyszenie

11 Kooperatywa to inaczej spółdzielnia, organizacja, zrzeszenie. 
odbywało rocznie około siedmiu tzw. spotkań dyskusyjnych ${ }^{12}$. Warto wskazać zagadnienia poruszane na wileńskich spotkaniach dyskusyjnych. Między innymi były to dyskusje na następujące tematy:

- prądy obecne wśród radykalnej młodzieży akademickiej,

- stosunek polskiej inteligencji do bolszewizmu,

- zatrudnienie młodzieży akademickiej po ukończeniu studiów,

- życie kulturalne,

- sprawozdania z wyjazdów zagranicznych.

Warto zauważyć, że referentami podczas tych spotkań byli m.in. Konrad Górski oraz Kazimierz Sławiński ${ }^{13}$.

Ważnym zadaniem realizowanym przez Stowarzyszenie było przygotowywanie projektów memoriałów i programów nauczania, które następnie przedstawiano na posiedzeniach (A UMK, sygn. 309/80/II, j. 43). Jednym z ważnych memoriałów, którego opracowania podjęło się Stowarzyszenie, był memoriał w sprawie Stypendium im. J. Piłsudskiego ${ }^{14}$. W piśmie do Stałej Delegacji Zrzeszeń i Związków Szkół Akademickich w Polsce poinformowano, że Stowarzyszenie Grona Nauczycielskiego w Wilnie postanowiło ustanowić Stypendium im. J. Piłsudskiego. Inny memoriał dotyczył kwestii poprawy bytu asystentów i adiunktów oraz reformy uposażenia profesorów wyższych zakładów naukowych i pomocniczych sił naukowych. W programie działania nie pominięto także sytuacji młodszych pracowników nauki, dlatego przedstawiono władzom ministerialnym postulaty nowelizacji założeń ustawowych, dotyczące pomocniczych sił naukowych, jak wówczas to określano, a byli to adiunkci, młodsi asystenci i asystenci. Wśród spraw odnoszących się do tej grupy nauczycieli znalazła się m.in. kwestia czasu pracy

12 Stowarzyszenie Grona Nauczycielskiego w Wilnie nie miało dobrych warunków lokalowych. Jak wynika z dokumentów, obrady odbywały się w lokalu, który posiadał braki, nie był m.in. odpowiednio umeblowany.

13 Kazimierz Sławiński (1870-1941), chemik, profesor USB, dziekan Wydziału Matematyczno-Przyrodniczego. Do Wilna przybył w 1919 roku, wcześniej w okresie warszawskim wykładał w szkołach średnich Warszawy, m.in. w szkole Leontyny Rudzkiej.

14 Tadeusz Czeżowski był referentem wniosku Stowarzyszenia Grona Nauczycielskiego USB o utworzenie przez poszczególne zrzeszenia stypendium dla osób pracujących naukowo. 
asystentów ${ }^{15}$. $Z$ kolei w kręgu spraw dotyczących nauki podnoszono także problem tzw. katedr nadzwyczajnych i równoległych. Jednym z ważnych celów działania Stowarzyszenia był udział w dziele opracowywania programów nauczania (A UMK, sygn. 309/80/II, j. 43). W dokumentacji znajduje się między innymi „Projekt programu filozofii dla drugiej klasy liceum ogólnokształcącego”. Projekt ten został opracowany przez Kazimierza Twardowskiego i Kazimierza Ajdukiewicza ${ }^{16}$. Ten przykład wskazuje na współpracę profesorów wileńskich i lwowskich. Projekt zawiera opis następujących zagadnień: materiał nauczania, lektury szkolne, działalność kółka filozoficznego, podręczniki, praca domowa uczniów, korelacja filozofii z innymi przedmiotami.

Lata trzydzieste XX wieku, jak powszechnie wiadomo, cechowały zmiany prawne dotyczące szkół wyższych. W programie działalności Stowarzyszenia znalazły się i te kwestie, tj. sprawy służbowe nauczycieli USB, wynikające $z$ prawnych uregulowań, a wpływające na ich status społeczny (A UMK, sygn. 309/80/II, j. 42). Członkowie Stowarzyszenia opracowali także memoriał w sprawie zmiany przepisów ustawy o szkołach akademickich ${ }^{17}$, w której dostrzeżono niekorzystne przepisy odnoszące się do pracowników szkół wyższych. Do takich niekorzystnych przepisów zaliczono:

- pozbawienie docentów po 55 roku życia prawa wykładania na uczelniach,

- pozbawienie profesorów honorowych prawa zasiadania w radach wydziałów,

- pozbawienie profesorów emerytów prawa wykładania na uczelniach,

- kasowanie katedr przy okazji ich reorganizacji.

Za prawne kwestie Stowarzyszenia odpowiadała tzw. Komisja Kodyfikacyjna składająca się głównie z przedstawicieli nauk prawnych.

15 Przedstawiono m.in. Projekt poprawek do rozporządzenia Prezydenta RP z dnia 24 II 1928 o stosunku służbowym profesorów Państwowych Szkół Akademickich i pomocniczych sił naukowych.

16 Współpraca ta była czymś naturalnym, bowiem Tadeusz Czeżowski należał do uczniów Kazimierza Twardowskiego.

17 Zob. Ustawa z dnia 15 marca 1933 r. o szkotach akademickich. Dziennik Ustaw RP, 29, poz. 247, 594-603. 
Innym ważnym stanowiskiem wypracowanym przez wileńskich członków Stowarzyszenia Grona Nauczycielskiego był „Memoriał w sprawie przywrócenia dodatku naukowego w uposażeniu profesorów", gdyż ich uposażenie, zdaniem członków Stowarzyszenia, odbiegało od uposażeń równoznacznych tej samej kategorii urzędników państwowych (tzn. IV i V kl.). Dla przykładu podano płace w innych zawodach: urzędnik departamentu (600 zł miesięcznie, naczelnik wydziału 500 zł miesięcznie, naczelnik więzienia 200 zł) (A UMK, sygn. 309/80/II, j. 42).

Kolejnym ważnym osiągnięciem Stowarzyszenia było opracowanie „Memoriału w sprawie Stypendium im. J. Piłsudskiego” oraz „Regulaminu Funduszu im. Marszałka J. Piłsudskiego”"18. Głównym zamysłem tej inicjatywy było uczczenie pamięci Józefa Piłsudskiego, który przeznaczał swoje pobory na nagrody przyznawane asystentom za ich prace naukowe. Ponadto wspierał wiele projektów naukowych na USB, których inicjatorami byli zarówno profesorowie, jak i studenci, żeby tylko wspomnieć czasopismo „Alma Mater Vilnensis”, funkcjonujące w latach 1922-1935 (Szulakiewicz 2017). Nic więc dziwnego, że znakomity rektor USB Marian Zdziechowski w swym cyklu wykładów skierowanych do młodzieży ( $W$ walce o duszę mtodzieży akademickiej) jeden $\mathrm{z}$ nich ( $\mathrm{w}$ dniu imienin Marszałka) poświęcił Piłsudskiemu (Zdziechowski 1927). Tuż po śmierci Piłsudskiego część członków Stowarzyszenia przystąpiła do opracowania regulaminu stypendium, a 14 grudnia 1935 roku zwołano nadzwyczajne posiedzenie Stowarzyszenia, aby zatwierdzić regulamin. Warto zauważyć, że wymagało to zmiany statutu Stowarzyszenia, co uczyniono w 1936 roku. Regulamin został zatwierdzony jednogłośnie. Celem tej inicjatywy było stworzenie możliwości wyjazdów zagranicznych dla pracowników naukowych. Czyniono to w myśl zasady, że dążeniem każdego państwa ceniącego kulturę jest posiadanie jak największej liczby najlepiej wykształconych pracowników naukowych, dlatego celem stypendium było stworzenie możliwości starania się o wyjazdy zagraniczne. Chodziło też o promowanie wymiany personalnej z uczelniami zagranicznymi (A UMK, sygn. 309/80/II, j. 26 i 33). Stypendia otrzymywali głównie magistrzy i doktorzy. Główną intencją tych działań było przygotowywanie kandydatów do obsadzania

Tekst regulaminu: Szulakiewicz (2019: 155-157). 
katedr uniwersyteckich w przyszłości, a udzielana im pomoc materialna miała sprzyjać ich przygotowaniu do pracy naukowej i pomóc w realizacji studyjnych wyjazdów zagranicznych. Wileńscy członkowie Stowarzyszenia Grona Nauczycielskiego zachęcali inne oddziały do przyłączenia się do tej akcji stypendialnej, argumentując następująco: „Pamiętać przy tym należy, że ludzi z wyższymi kwalifikacjami naukowymi potrzeba w Polsce nie tylko do obsadzania katedr w uniwersytetach i innych szkołach akademickich, ale także do obsadzania stanowisk w sądownictwie, $w$ departamentach ministerstw mających czuwać nad reformą administracji i skarbowości, w bankach państwowych itd." (A UMK, sygn. 309/80/II, j 43, k. 2). Tak więc pomysł organizacji funduszu stypendialnego miał służyć przysporzeniu Polsce ludzi wykształconych.

\section{Uwagi końcowe}

Podsumowując uwagi o jednym ze stowarzyszeń utworzonych przez nauczycieli akademickich USB i dla nauczycieli, należy stwierdzić, że działało ono przede wszystkim na rzecz rozwoju nauki. Znaczenie aktywności Stowarzyszenia Grona Nauczycielskiego działającego przy wileńskiej uczelni można ustalić analizując biografie wybitnych uczonych, a zarazem członków i współpracowników tegoż Stowarzyszenia: Tadeusza Czeżowskiego (filozofa), Wacława Dziewulskiego (fizyka), Władysława Dziewulskiego (astronoma), Stanisława Kościałkowskiego (historyka), Manfreda Kridla (historyka literatury), Jana Oko (filologa klasycznego), ks. Leona Puciaty (prof. dogmatyki), bł. Michała Sopoćki, spowiednika św. Faustyny Kowalskiej, wspomnianego już ks. prof. Bronisława Żongołłowicza, Konrada Górskiego (historyka literatury i kultury), Bogumiła Jasinowskiego (historyka filozofii) ${ }^{19}$. Do grona członków Stowarzyszenia w ostatnich latach jego funkcjonowania (tuż przed II wojną światową) dołączył filozof i pedagog Ludwik Chmaj, który otrzymał na USB katedrę uniwersytecką (Szulakiewicz 2003, 2019). Trzeba stwierdzić, że członkowie Stowarzyszenia przede wszystkim skupili się w swej

19 O działalności niektórych spośród wymienionych członków Stowarzyszenia zob.: Czeżowski (1973), Gołubiew (1974), Jadacki (1994), Dalecka (2003), Szulakiewicz (2010, 2017), Tomaszewski (2018). 
działalności na realizacji pierwszego celu wpisanego w statucie, tj. popierania rozwoju nauki, przygotowania młodej kadry naukowej i pomocy w rozwoju naukowym kandydatom do katedr uniwersyteckich. Jednak nie mniej ważna była pomoc materialna i opieka nad rodzinami profesorskimi, które niekiedy znajdowały się w trudnych warunkach bytowych. Liczne formy organizacyjne współdziałania członków Stowarzyszenia sprzyjały także realizacji celu, który określono w dokumencie założycielskim jako „zbliżenie koleżeńskie”, czyli chodziło o integrację środowiska naukowego.

Po dokonanej analizie źródeł nasuwa się jeszcze jedno ogólne spostrzeżenie charakteryzujące działalność nauczycieli akademickich Uniwersytetu Stefana Batorego w Wilnie. Otóż trzeba podkreślić niezwykle wszechstronną działalność ówczesnych profesorów uniwersyteckich w obszarze naukowym, dydaktycznym i organizacyjno-naukowym. Ta niewiarygodna aktywność profesorów być może podyktowana była wyjątkową atmosferą Wilna. Charakterystykę tej atmosfery można także znaleźć w literaturze naukowej i pięknej. Słusznie Czesław Miłosz, jeden z absolwentów wileńskiego uniwersytetu, napisał: „Wilna nie da się wyeliminować z dziejów kultury polskiej, a to ze względu na Mickiewicza, Słowackiego, Piłsudskiego" (Miłosz 1990). Dodam do tych słów, że nie można $z$ historii nauki polskiej wyeliminować wybitnych uczonych z wileńskiej Wszechnicy $\mathrm{i}$ ich zasług dla nauki polskiej.

Jak już wspomniałam na wstępie, niniejszy artykuł nie stanowi wyczerpującego studium podjętego zagadnienia, jest jedynie zarysem problemu i wymaga dalszych badań, w tym wykorzystania wskazanych $\mathrm{w}$ artykule materiałów archiwalnych znajdujących się w spuściźnie Tadeusza Czeżowskiego i w literaturze pamiętnikarskiej tamtego okresu.

\section{Bibliografia}

\section{1. Źródła archiwalne}

Archiwum Uniwersytetu Mikołaja Kopernika (w skrócie: A UMK): A UMK, sygn. 309/80/II, j. 20-43. A UMK, Spuścizna Tadeusza Czeżowskiego. Dokumenty Stowarzyszenia Grona Nauczycielskiego, sygn. 309/80/II, j. 20-43. 


\section{2. Źródła drukowane}

Rocznik Uniwersytetu Stefana Batorego w Wilnie 1938-1939, Wilno: Nakładem Uniwersytetu Stefana Batorego.

Ustawa z dnia 15 marca 1933 r. o szkołach akademickich. Dziennik Ustaw RP, 29, poz. 247, 594-603.

\section{Literatura pamiętnikarska}

Czeżowski T. (1988). Wspomnienia, [w:] I. Stasiewicz-Jasiukowa, M. Miśkowiec (red.), Uczeni polscy o sobie, t. 1, Warszawa: Młodzieżowa Agencja Wydawnicza, s. 126-131.

Górski K. (1995). Pamiętniki, Toruń: Wydawnictwo Comer.

Grochowina S. (2012). Kolankowski Ludwik 1882-1956. Zapiski pamiętnikarskie, Toruń: Wydawnictwo Naukowe Uniwersytetu Mikołaja Kopernika.

Lutosławski W. (1933). Jeden tatwy żywot, Warszawa: Wydawnictwo Monolit.

Meysztowicz W. (2012). Gawędy o czasach i ludziach, Łomianki: Wydawnictwo LTW.

Miłosz C. (1990). Do Tomasza Venclovy, [w:] tegoż, Zaczynajac od moich ulic, Wrocław: Wydawnictwo Dolnośląskie.

Ruszczyc F. (1996). Dzienniki, cz. 2: W Wilnie 1919-1932, Wybór, układ, opracowanie, wstęp i posłowie E. Ruszczyc, Warszawa: Wydawnictwo „Secesja”.

Sławińska I. (2004). Szlakami moich wód..., Lublin: Wydawnictwo Norbertinum.

Stomma S. (1998). Trudne lekcje historii, Kraków: Wydawnictwo Znak.

Tatarkiewiczowie T. i W. (2011). Wspomnienia, Poznań: Wydawnictwo Zysk i S-ka.

Zgorzelski C. (2006). Przywotane z pamięci, wyd. 2, Lublin: Wydawnictwo Norbertinum.

Żongołłowicz B. (2004). Dzienniki 1930-1936, oprac. D. Zamojska, Warszawa: Przegląd Wschodni Retro-Art.

\section{Opracowania}

Czeżowski T. (1973). Filozofia polska w dwudziestoleciu międzywojennym. (Zarys rozwoju), „Studia Filozoficzne”, nr 2, s. 61-69.

Dalecka T. (2003). Dzieje polonistyki wileńskiej 1919-1939, Kraków: Wydawnictwo Towarzystwa Naukowego „Societas Vistulana”. 
Gawrońska-Garstka M. (2016). Uniwersytet Stefana Batorego w Wilnie. Uczelnia ziem pótnocno-wschodnich Drugiej Rzeczypospolitej (1919-1939) w świetle źródet, Poznań: Wydawnictwo Rys.

Gołubiew A. (1971). Wychowawca, [w:] tegoż, Unoszeni historiq, Kraków: Wydawnictwo Znak.

Jadacki J.J. (1994). Stawni Wilnianie filozofowie, Wilno: Wydawnictwo Polskie w Wilnie.

Krasnodębski J. (2019). Z Wilna nad Wiliq do „Wilna nad Wista”. Ekspatriacja i osiedlenie mieszkańców Wileńszczyzny w Toruniu (1944-1948), Toruń: Wydawnictwo Naukowe Uniwersytetu Mikołaja Kopernika.

Opacki Z. (1998). Reaktywacja czy powstanie? Dyskusje wokót utworzenia Uniwersytetu Stefana Batorego w Wilnie w latach 1918-1919, „Kwartalnik Historyczny", nr 3, s. 49-64.

Piechnik L., Puchowski K. (red.) (1996). Z dziejów Almae Matris Vilnensis. Ksiegga pamiątkowa ku czci 400-lecia zatożenia i 75-lecia wskrzeszenia Uniwersytetu Wileńskiego, Kraków: Wydawnictwo WAM.

Pigoń S. (1929). Kota naukowe studentów Uniwersytetu Stefana Batorego w latach 1919-1929, [w:] Ksiega Pamiątkowa ku uczczeniu CCCL rocznicy zatożenia i $X$ wskrzeszenia Uniwersytetu Wilenskiego, t. 2: Dziesięciolecie 1919-29, Wilno: Nakładem Uniwersytetu Stefana Batorego, s. 595-614.

Szulakiewicz W. (2003). Ludwik Chmaj - zarys biografii i twórczości pedagogicznej, „Rozprawy z Dziejów Oświaty”, t. 42, s. 161-182.

Szulakiewicz W. (2010). Za przyktadem mistrza. Tadeusza Czeżorwskiego (1889-1981) stużba uniwersytetowi i nauce, „Rozprawy z Dziejów Oświaty”, t. 47, s. 109-127.

Szulakiewicz W. (2017). „Alma Mater Vilnensis” (1922-1935) - źródto do dziejów życia uniwersyteckiego, „Acta Universitatis Nicolai Copernici Pedagogika", t. 34, nr 2, s. 9-32.

Szulakiewicz W. (2019). Pedagogika na Uniwersytecie Stefana Batorego, Toruń: Wydawnictwo Naukowe Uniwersytetu Mikołaja Kopernika.

Tomaszewski P. (2018). Uniwersytet Stefana Batorego w Wilnie w latach 1919-1939. Studium z dziejów organizacji i postaw ideowych studentów, Torun: Wydawnictwo Naukowe Uniwersytetu Mikołaja Kopernika.

Wrzosek A. (1929). Wskrzeszenie Uniwersytetu Wileńskiego w r. 1919, [w:] Ksiega Pamiątkowa ku uczczeniu CCCL rocznicy zatożenia i $X$ wskrzeszenia Uniwersytetu Wileńskiego, t. 2: Dziesięciolecie 1919-29, Wilno: Nakładem Uniwersytetu Stefana Batorego, s. 1-32.

Zdziechowski M. (1927). W walce o dusze mtodzieży akademickiej z czasów rektorstwa, Wilno: Księgarnia Stowarzyszenia Nauczycielstwa Polskiego w Wilnie. 


\section{ADRES DO KORESPONDENCJI}

Prof. dr hab. Władysława Szulakiewicz

Uniwersytet Mikołaja Kopernika w Toruniu

Wydział Filozofii i Nauk Społecznych

Instytut Nauk Pedagogicznych

e-mail: jszulak@uni.torun.pl 